\title{
Recycling and balance of nutrients at alternative fertilizer systems of sugar beet
}

\section{Pavuk I.}

Vinnytsia National agrarian university, Soniachna Str., 3, Vinnytsia, 21008, Ukraine; e-mail: mate-matiks@gmail.com

The purpose. To study features of recycling of nutrients in agrocenosis of sugar beet and to generate their equilibrated balance at alternative organic-mineral fertilizer systems. Methods. Short-term field and laboratory-analytical with mathematical processing of the gained results. Results. They show circulation and balance of nitrogen, phosphorus and potassium at cultivation of sugar beet with the use of traditional and alternative fertilizer systems. Conclusions. Use at cultivation of sugar beet of $5 \mathrm{t} /$ hectare of straw + green manure crop $+\mathrm{N}_{90} \mathrm{P}_{60} \mathrm{~K}_{90}++\mathrm{N}_{50}$. Maximus, $4 \mathrm{~kg} /$ hectare is specified by highly efficient and ecologically balanced fertilizer system. Such application of fertilizers formed the equilibrated balance of nutrients in agrocenosis of sugar beet: nitrogen and phosphorus $-5 \mathrm{~kg} / \mathrm{hectare}+10 \mathrm{~kg} / \mathrm{hectare}$ accordingly, and deficiency of potassium (at level of $69 \mathrm{~kg} / \mathrm{hectare}$ ). Use as fertilizer of haulm of sugar beet refunded in soil $49 \%$ of nitrogen, $40 \%$ of phosphorus, and $50 \%$ of potassium (from their economic remo-val). That made it possible to enter $139 \mathrm{~kg} /$ hectare of nitrogen, $35 \mathrm{~kg} /$ hectare of phosphorus, and $161 \mathrm{~kg} /$ hectare of potassium under the next crop in rotation in the form of easily accessible organic compounds.

Key words: nutrients, balance, recycling, sugar beet.

Introduction. Modern technologies of growing crops require reduction of economic costs and biogenic loading in agroecosystems [1], [2], [3]. Application for the fertilizer of the by-products of cultivated crops enriches the soil with organic matter, reduces the volume of nutrients removal from the soil and due to the processes of recirculation improves the nutrition of plants [4], [5]. Alternative organic-mineral systems of fertilizers with application of winter wheat straw and green mass of white mustard can significantly reduce the cost of using fertilizers, while ensuring the sustainability of crop growing technologies [6], [7], [8], [9]. In the conditions of the acute deficit of manure shortage and application the alternative system of sugar beet fertilization deserves special attention as it allows achieving high its productivity on the basis of ecologically balanced and economically efficient use of fertilizers [10], [11].

Research purpose was to study the peculiarities of the recycling of nutrients in the agro-cenosis of sugar beet and to form a balanced balance of them under alternative organic-mineral systems of fertilizers.

Materials and research methods. The research was carried out in the conditions of the stationary field experiment (2015-2017) of the Uladovo-Lulinetska research-breeding station, the zone of sufficient moisture of the Forest-Steppe of Ukraine.

Drilling area $-75 \mathrm{~m}^{2}$, accounting area $-50 \mathrm{~m}^{2}$, placement of the variants in experiments - systematic consistent, repetition of the experiment is four times. The sugar beet hybrid - "Bulava", cultivation agrotechnic is generally accepted for the Forest-Steppe Zone.

Soil of the research plot is leached black soil which characterized by the following agrochemical properties: organic matter content by Turin $-4.0-4.2 \%, \mathrm{pH}$ salt solution $-5.9-6.5$, hydrolytic acid $(\mathrm{Hg})$ by Kappen - 1.18-1.30 mg-equ./100 g of soil, sum of absorbed bases (S) by Kappen-Gilkovits - 24.4-27.6 mgequ./100 g of soil, alkaline hydrolyzed nitrogen at Cornfield $-130-140 \mathrm{mg} / \mathrm{kg}$ of soil, mobile phosphoric and potassium by Chirikov - $140-160$ and $75-80 \mathrm{mg} / \mathrm{kg}$ of soil.

Fertilizers were applied in the form of ammonium nitrate, simple granular superphosphate and potassium chloride. Organic fertilizers were applied in the form of alternative sources of the organic matter - the green 
mass of the after harvesting green manure crop of mustard white (average yield $-26 \mathrm{t} / \mathrm{ha}$ ) and straw of winter wheat $-5 \mathrm{t} / \mathrm{ha}$.

When carrying out calculations of the balance of nutrients in agrocenosis of the beet sugar the nutrient supply to the soil with straw of winter wheat predecessor or green manure were not taken into account.

The content of nutrients in vegetative samples was determined after wet ashing by Ginzburg and etc.: nitrogen - by Keldal according to DSTU 7169-2010, phosphorus - according to GOST 26657-97, potassium - on a flame photometer.

Research results and their discussion. Studies curried out in the temporary field experiment of the Uladovo-Lulinetska research-breeding station shown that the use of alternative organicmineral systems of fertilizers ensured the yield of sugar beet at the level of 59-65 $t /$ ha, which exceeded the control without fertilizers per 14,9-21,3 t/ha. Under such yield, the sugar beet plants with roots have taken: nitrogen - 119-146 kg/ha, phosphorus - 40-50, potassium - 128-158; leaves - respectively 115-139, 20-33 and $137-161 \mathrm{~kg} / \mathrm{ha}$ (table 1 ).

Table 1. Removal of the nutrients by sugar beet plants at the harvest period, average 2015-2017, kg/ha

\begin{tabular}{|c|c|c|c|c|c|c|c|c|c|c|}
\hline \multirow{2}{*}{$\begin{array}{l}\text { № } \\
\text { var. }\end{array}$} & \multirow{2}{*}{\multicolumn{2}{|c|}{ Variant }} & \multirow{2}{*}{$\begin{array}{l}\text { Roots } \\
\text { yield, } \\
\text { t/ha }\end{array}$} & \multicolumn{3}{|c|}{ Removal by roots } & \multirow{2}{*}{$\begin{array}{c}\text { Leaves } \\
\text { yield, } \\
\text { t/ha }\end{array}$} & \multicolumn{3}{|c|}{ Removal by leaves } \\
\hline & & & & $\mathrm{N}$ & $\mathrm{P}_{2} \mathrm{O}_{5}$ & $\mathrm{~K}_{2} \mathrm{O}$ & & $\mathrm{N}$ & $\mathrm{P}_{2} \mathrm{O}_{5}$ & $\mathrm{~K}_{2} \mathrm{O}$ \\
\hline 1 & \multicolumn{2}{|c|}{ Without fertilizers (control) } & 44,2 & 85 & 29 & 93 & 28,1 & 88 & 20 & 102 \\
\hline 2 & \multirow{7}{*}{ 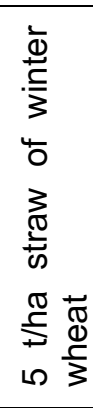 } & $\begin{array}{l}\text { Without fertilizers } \\
\text { (control) }\end{array}$ & 47,1 & 93 & 31 & 99 & 29,3 & 90 & 20 & 106 \\
\hline 3 & & $\mathrm{~N}_{90} \mathrm{P}_{60} \mathrm{~K}_{90}$ & 59,1 & 119 & 40 & 128 & 35,7 & 115 & 26 & 137 \\
\hline 4 & & $\mathrm{~N}_{120} \mathrm{P}_{90} \mathrm{~K}_{120}$ & 59,6 & 125 & 41 & 136 & 35,8 & 115 & 27 & 138 \\
\hline 5 & & $\mathrm{~N}_{90} \mathrm{P}_{60} \mathrm{~K}_{90}+{ }^{*} \mathrm{~N}_{50}$ & 61,7 & 132 & 43 & 140 & 37,6 & 124 & 27 & 143 \\
\hline 6 & & $\mathrm{~N}_{120} \mathrm{P}_{90} \mathrm{~K}_{120}+{ }^{*} \mathrm{~N}_{50}$ & 62,2 & 137 & 44 & 144 & 38,0 & 127 & 28 & 147 \\
\hline 7 & & $\begin{array}{l}\mathrm{N}_{90} \mathrm{P}_{60} \mathrm{~K}_{90}+{ }^{*} \mathrm{~N}_{50}+ \\
\text { Maximus, } 4 \mathrm{~kg} / \mathrm{ha}\end{array}$ & 63,2 & 137 & 45 & 145 & 40,1 & 136 & 30 & 158 \\
\hline 8 & & $\begin{array}{l}\mathrm{N}_{120} \mathrm{P}_{90} \mathrm{~K}_{120}+{ }^{+}{ }^{*} \mathrm{~N}_{50} \\
+ \text { Maximus, } 4 \mathrm{~kg} / \mathrm{ha}\end{array}$ & 63,2 & 137 & 44 & 147 & 40,7 & 136 & 31 & 159 \\
\hline 9 & \multirow{7}{*}{ 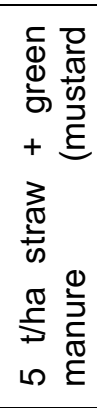 } & $\begin{array}{ll}\text { Without } & \text { fertilizers } \\
\text { (control) } & \end{array}$ & 47,3 & 92 & 32 & 102 & 28,7 & 88 & 21 & 104 \\
\hline 10 & & $\mathrm{~N}_{90} \mathrm{P}_{60} \mathrm{~K}_{90}$ & 60,2 & 122 & 43 & 136 & 37,1 & 120 & 28 & 140 \\
\hline 11 & & $\mathrm{~N}_{120} \mathrm{P}_{90} \mathrm{~K}_{120}$ & 61,5 & 129 & 44 & 144 & 37,7 & 123 & 28 & 143 \\
\hline 12 & & $\mathrm{~N}_{90} \mathrm{P}_{60} \mathrm{~K}_{90}+{ }^{*} \mathrm{~N}_{50}$ & 62,6 & 133 & 45 & 147 & 37,8 & 129 & 30 & 148 \\
\hline 13 & & $\mathrm{~N}_{120} \mathrm{P}_{90} \mathrm{~K}_{120}+{ }^{*} \mathrm{~N}_{50}$ & 63,3 & 143 & 47 & 150 & 39,4 & 136 & 31 & 157 \\
\hline 14 & & $\begin{array}{l}\mathrm{N}_{90} \mathrm{P}_{60} \mathrm{~K}_{90}+{ }^{*} \mathrm{~N}_{50}+ \\
\text { Maximus, } 4 \mathrm{~kg} / \mathrm{ha}\end{array}$ & 65,1 & 145 & 50 & 159 & 40,7 & 139 & 33 & 161 \\
\hline 15 & & $\begin{array}{l}\mathrm{N}_{120} \mathrm{P}_{90} \mathrm{~K}_{120}+{ }^{*}{ }^{*} \mathrm{~N}_{50} \\
+ \text { Maximus, } 4 \mathrm{~kg} / \mathrm{ha}\end{array}$ & 65,5 & 146 & 50 & 158 & 40,3 & 136 & 32 & 158 \\
\hline \multirow{3}{*}{$\mathrm{NIR}_{0,05}$} & \multicolumn{2}{|c|}{ fund of organic fertilizers } & 1,1 & - & - & - & 0,6 & - & - & - \\
\hline & \multirow{2}{*}{\multicolumn{2}{|c|}{ system of fertilizers }} & 2,4 & - & - & - & 1,4 & - & - & - \\
\hline & & & 3,3 & - & - & - & 1,8 & - & - & - \\
\hline
\end{tabular}

${ }^{*}$ Compensatory dose of nitrogen

For the use of different combinations of fertilizers under sugar beet on the fond of $5 \mathrm{t} / \mathrm{ha}$ straw + green manure, the yield of roots compared with the application of fertilizers on the fond of straw was slightly higher - per 1.1-2.3 t/ha, which was accompanied by an increase in economic withdrawal of nitrogen - per 8-12 kg / ha, phosphorus - per 5-8, potassium - per $11-17 \mathrm{~kg} / \mathrm{ha}$.

The highest removal of nutrients was observed for the application of $5 \mathrm{t} / \mathrm{ha}$ straw + green manure + $\mathrm{N} 90 \mathrm{P} 60 \mathrm{~K} 90+\mathrm{N} 50+$ Maximus, $4 \mathrm{~kg} / \mathrm{ha}$ : economic removal of nitrogen $-284 \mathrm{~kg} / \mathrm{ha}$, phosphorus -83 , potassium $-320 \mathrm{~kg} / \mathrm{ha}$. Compared to the growing of sugar beet on the fond of organic fertilizers $(5 \mathrm{t} / \mathrm{ha}$ straw + green manure), the economic removal of nitrogen increased - per $104 \mathrm{~kg} / \mathrm{ha}$, phosphorus - per 30, potassium - per $110 \mathrm{~kg} / \mathrm{ha}$. 
The application of a single dose of fertilizers ( 5 t/ha straw + green manure + N90P60K90) compared with repeated application of them on the fond of organic fertilizers reduced the yield of sugar beet per $4.9 \mathrm{t} / \mathrm{ha}$ and was accompanied by a decrease in economic withdrawal of nitrogen - per $42 \mathrm{~kg} / \mathrm{ha}$, phosphorus -12 , potassium - per $44 \mathrm{~kg} / \mathrm{ha}$.

For multiple use of fertilizers on the fond of straw application (straw + N90P60K90 + N50 + Maximus, 4 $\mathrm{kg} / \mathrm{ha}$ ), the economic removal of nitrogen was $273 \mathrm{~kg} / \mathrm{ha}$, phosphorus -75 , potassium $-303 \mathrm{~kg} / \mathrm{ha}$, which in comparison with the only straw application was higher - respectively per 90,24 and $98 \mathrm{~kg} / \mathrm{ha}$; in comparison with the addition of $5 \mathrm{t} / \mathrm{ha}$ straw + N90P60K90 - respectively per 39,9 and $38 \mathrm{~kg} / \mathrm{ha}$.

Thus, the application of alternatives organic-mineral fertilizers for sugar beet in comparison with crop cultivation on the fond of only organic fertilizers significantly increased yields and increased the removal of nutrients with economic yield in 1.3-1.5 times.

Alternative systems of fertilizers with the use of by-products involved a significant amount of nutrients to the processes of recirculation, turning nitrogen from its economic removal - on 48-51\%, phosphorus - on 39$41 \%$, potassium - on $50-52 \%$. The specified amount of nutrients after the rapid mineralization of the sugar beet leaves served as a source of nutrition for the next crop, which was mainly grown on aftereffect of fertilizers. When plowing in leaves of sugar beet, the next crop in rotation received nitrogen in easily accessible form - 88-139 kg/ha, phosphorus - 20-33, potassium - 102-161 kg/ha. An alternative organicmineral system of fertilizers created a solid basis for increasing the yield of crops grown in the aftereffect of fertilizers, providing them with a sufficiently high amount of nutrients in easily accessible forms (table 2).

Table 2. Balance and recirculation of the nutrients in the agrocenosis of sugar beet, average 20152017

\begin{tabular}{|c|c|c|c|c|c|c|c|c|}
\hline № & \multirow{2}{*}{\multicolumn{2}{|c|}{ Variant }} & \multicolumn{3}{|c|}{ Balance, $\pm \mathrm{kg} / \mathrm{ha}$} & \multicolumn{3}{|c|}{ Recirculation, \% } \\
\hline var. & & & $\mathrm{N}$ & $\mathrm{P}_{2} \mathrm{O}_{5}$ & $\mathrm{~K}_{2} \mathrm{O}$ & $\mathrm{N}$ & $\mathrm{P}_{2} \mathrm{O}_{5}$ & $\mathrm{~K}_{2} \mathrm{O}$ \\
\hline 1 & \multicolumn{2}{|c|}{ Without fertilizers (control) } & -86 & -29 & -93 & 51 & 41 & 52 \\
\hline 2 & \multirow{7}{*}{ 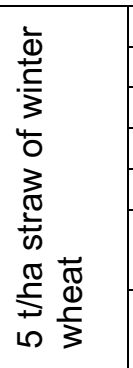 } & Without fertilizers (control) & -93 & -31 & -99 & 49 & 39 & 52 \\
\hline 3 & & $\mathrm{~N}_{90} \mathrm{P}_{60} \mathrm{~K}_{90}$ & -29 & +20 & -38 & 49 & 39 & 52 \\
\hline 4 & & $\mathrm{~N}_{120} \mathrm{P}_{90} \mathrm{~K}_{120}$ & -5 & +49 & -16 & 48 & 40 & 50 \\
\hline 5 & & $\mathrm{~N}_{90} \mathrm{P}_{60} \mathrm{~K}_{90}+{ }^{*} \mathrm{~N}_{50}$ & +8 & +17 & -50 & 48 & 39 & 51 \\
\hline 6 & & $\mathrm{~N}_{120} \mathrm{P}_{90} \mathrm{~K}_{120}+{ }^{*} \mathrm{~N}_{50}$ & +33 & +46 & -24 & 48 & 39 & 51 \\
\hline 7 & & $\begin{array}{l}\mathrm{N}_{90} \mathrm{P}_{60} \mathrm{~K}_{90}+{ }^{+}{ }^{*} \mathrm{~N}_{50}+ \\
\text { Maximus, } 4 \mathrm{~kg} / \mathrm{ha}\end{array}$ & +3 & +15 & -55 & 50 & 40 & 52 \\
\hline 8 & & $\begin{array}{lll}\mathrm{N}_{120} \mathrm{P}_{90} \mathrm{~K}_{120} & + & { }^{*} \mathrm{~N}_{50} \\
+ \text { +Maximus, } & 4 \mathrm{~kg} / \mathrm{ha}\end{array}$ & +33 & +46 & -28 & 50 & 41 & 52 \\
\hline 9 & \multirow{7}{*}{ 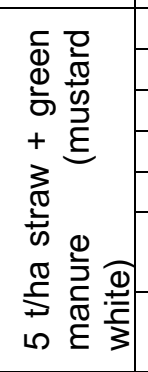 } & Without fertilizers (control) & -92 & -32 & -102 & 49 & 40 & 51 \\
\hline 10 & & $\mathrm{~N}_{90} \mathrm{P}_{60} \mathrm{~K}_{90}$ & -32 & +17 & -46 & 50 & 39 & 51 \\
\hline 11 & & $\mathrm{~N}_{120} \mathrm{P}_{90} \mathrm{~K}_{120}$ & -9 & +46 & -24 & 49 & 39 & 50 \\
\hline 12 & & $\mathrm{~N}_{90} \mathrm{P}_{60} \mathrm{~K}_{90}+{ }^{*} \mathrm{~N}_{50}$ & +7 & +15 & -57 & 49 & 40 & 50 \\
\hline 13 & & $\mathrm{~N}_{120} \mathrm{P}_{90} \mathrm{~K}_{120}+{ }^{*} \mathrm{~N}_{50}$ & +27 & +43 & -30 & 49 & 40 & 51 \\
\hline 14 & & $\begin{array}{l}\mathrm{N}_{90} \mathrm{P}_{60} \mathrm{~K}_{90}+{ }^{*} \mathrm{~N}_{50}+ \\
\text { Maximus, } 4 \mathrm{~kg} / \mathrm{ha}\end{array}$ & -5 & +10 & -69 & 49 & 40 & 50 \\
\hline 15 & & $\begin{array}{l}\mathrm{N}_{120} \mathrm{P}_{90} \mathrm{~K}_{120}+{ }^{+}{ }^{*} \mathrm{~N}_{50} \quad+ \\
\text { Maximus, } 4 \mathrm{~kg} / \mathrm{ha}\end{array}$ & +24 & +40 & -38 & 48 & 39 & 50 \\
\hline
\end{tabular}

Note: balance - when leaving the leaves of sugar beet on the field; recirculation - from economic removal

The return to the soil of the leaves significantly reduced the nutrient load in the agroecosystem of sugar beet. Calculations of the balance of nutrients for plowing on fertilizer leaves of the sugar beet showed that roots of sugar beet crops with the yield of 60-65 t/ha have removed from the soil: nitrogen - 122-146 kg/ha, phosphorus - 43-50 kg/ha, potassium - 136-159 kg/ha, which was $50-60 \%$ from the economic removal.

For growing sugar beets on the background of $5 \mathrm{t} / \mathrm{ha}$ of straw without fertilizers with the subsequent plowing in the soil of the leaves, the sugar beet plants removed from the soil: nitrogen $-93 \mathrm{~kg} / \mathrm{ha}$, 
phosphorus -31 , potassium - 99; on the background of $5 \mathrm{t} /$ ha straw + green mass of mustard white respectively 92,32 and $102 \mathrm{~kg} / \mathrm{ha}$.

When applying $5 \mathrm{t} / \mathrm{ha}$ straw $+\mathrm{N} 90 \mathrm{P} 60 \mathrm{~K} 90+\mathrm{N} 50+$ Maximus, $4 \mathrm{~kg} / \mathrm{ha}$, it was formed a balanced balance of nutrients in agrocenosis of sugar beet plants by nitrogen and phosphorus - respectively $+3 \mathrm{~kg} / \mathrm{ha}$ and +15 $\mathrm{kg} / \mathrm{ha}$; with a deficit of potassium at a level of $55 \mathrm{~kg} / \mathrm{ha}$.

For the application of $5 \mathrm{t} / \mathrm{ha}$ straw + green manure $+\mathrm{N} 90 \mathrm{P} 60 \mathrm{~K} 90+\mathrm{N} 50+$ Maximus, $4 \mathrm{~kg} / \mathrm{ha}$, the balance of the nitrogen was slightly negative $--5 \mathrm{~kg} / \mathrm{ha}$, phosphorus $-+10 \mathrm{~kg} / \mathrm{ha}$, potassium $--69 \mathrm{~kg} / \mathrm{ha}$.

Thus, the formation of stable conditions for sugar beet cultivation and receiving the yield of the roots at the level of 60-65 t/ha for the alternative organic-mineral systems of fertilizers requires the application of nitrogen fertilizers at the level of $140 \mathrm{~kg} / \mathrm{ha}$, phosphorous $-50 \mathrm{~kg} / \mathrm{ha}$, potassium $-160 \mathrm{~kg} / \mathrm{ha}$.

\section{Conclusions}

1. In conditions of sufficient moisture, the most effective alternative organic-mineral system of fertilizers was defined $5 \mathrm{t} / \mathrm{ha}$ straw + green manure $+\mathrm{N} 90 \mathrm{P} 60 \mathrm{~K} 90+\mathrm{N} 50+$ Maximus, $4 \mathrm{~kg} / \mathrm{ha}$. The application of the specified amount of organic and mineral fertilizers allowed the yield of sugar beet roots to $65.1 \mathrm{t} / \mathrm{ha}$, and when plowing in leaves for the fertilizer, the plants carried out from the soil: nitrogen $-145 \mathrm{~kg} / \mathrm{ha}$, phosphorus $-50 \mathrm{~kg} / \mathrm{ha}$, potassium - $159 \mathrm{~kg} / \mathrm{ha}$, which was $50-60 \%$ from their economic take-up.

2. Application under the sugar beet of $5 \mathrm{t} /$ ha straw + green manure $+\mathrm{N} 90 \mathrm{P} 60 \mathrm{~K} 90+\mathrm{N} 50+$ Maximus, 4 $\mathrm{kg} / \mathrm{ha}$ formed a balanced balance of nutrients in agrocenosis of sugar beet plants by nitrogen and phosphorus - respectively $-5 \mathrm{~kg} / \mathrm{ha}$ and $+10 \mathrm{~kg} / \mathrm{ha}$; with a deficit of potassium at $69 \mathrm{~kg} / \mathrm{ha}$.

3. By biologization of sugar beet cultivation (return leaves to the soil) and alternative organic-mineral system of fertilizers due to the processes of recirculation, into the soil it was returned from their economic removal: nitrogen $-48-50 \%$, phosphorus $-39-41 \%$, potassium $-50-52 \%$. This allowed for the following crop in the rotation in the form of easy available organic compounds to apply nitrogen $-115-139 \mathrm{~kg} / \mathrm{ha}$, phosphorus - 20-33, potassium - 137-161 kg/ha.

\section{Bibliography}

1. Ivanina V.V. (2016). Biolohizatsiia udobrennia kultur u sivozminakh. Kyiv: Komprynt. 328 s. [In Ukrainian].

2. Beegle D.B., Carton O.T., Bailey J.S. (2000). Nutrient management planning: justification, theory, practice. J. Environment Quality. №29. P. 72-79.

3. Polovyi V.M. (2007). Optymizatsiia system udobrennia u suchasnomu zemlerobstvi. Monohrafiia. Rivne: Volynski oberehy. $320 \mathrm{~s}$. [In Ukrainian].

4. Tsvei Ya.P., Ivanina V.V., Tsebro Yu.M. et al. (2012). Balans elementiv zhyvlennia u zerno-buriakovii sivozmini zalezhno vid systemy udobrennia. Visnyk ahrarnoi nauky. №1. S. 33-37. [In Ukrainian]

5. Zaryshniak A.S., Ivanina V.V., Kolibabchuk T.V. (2012). Stabilizatsiia biohennoho balansu ta produktyvnist zernoburiakovoi sivozminy. Visnyk ahrarnoi nauky. № 4. S. 26-30. [In Ukrainian].

6. Anysymova T.lu. (2002). Эffektyvnost solomы y balans pytatelnыkh эlementov $v$ zvene sevooborota s liupynom. Ahrokhymyia. № 5. S. 63-65. [In Russian].

7. Tsvei Ya.P., Kasianchuk F.P. (2004). Vykorystannia pozhnyvnoi hirchytsi pry vyroshchuvanni tsukrovykh buriakiv. Tsukrovi buriaky. № 3. S. 14-15. [In Ukrainian].

8. Ivanov V.P., Prasol V.I., Mishchenko Yu.H., Kovalenko M.P. (2003). Pobichna produktsiia ta promizhni kultury yak faktor stabilizatsii rodiuchosti gruntu. Zbirnyk naukovykh prats. Spets. vyp. IZ NAAN. Kyiv. S. 48-51. [In Ukrainian].

9. Tsvei Ya.P. (2014). Rodiuchist gruntiv i produktyvnist sivozmin. Kyiv: Komprynt. 413 c. [In Ukrainian].

10. Magdoff F., Lanyon L., Liebhardt B. (1997). Nutrient cycling, transformations and flows: Implications for a more sustainable agriculture. Advances in Agronomy. №60. P. 2-73.

11. Draycott A.P., Christenson D.R. (2003). Nutrients for sugar beet production. Soil-Plant Relationships. CABI: Wallingford. P. 7-181. 